\title{
PENGARUH PEMBERIAN KOLKISIN TERHADAP JUMLAH KROMOSOM BAWANG PUTIH (Allium sativum) LOKAL KULTIVAR DOULU
}

\author{
Tumiur Gultom \\ 1) Tenaga Pengajar Program Studi Biologi, Jurusan Biologi, FMIPA Universitas Negeri Medan. \\ Kampus: Jl. Willem Iskandar Pasar V Medan Estate 20221. \\ tumiurgultom@unimed.ac.id
}

\begin{abstract}
ABSTRAK
Bawang putih lokal kultivar Doulu berasal dari Desa Doulu Kabupaten Karo Sumatera Utara. Bawang putih lokal Doulu dikenal luas oleh masyarakat di Sumatera Utara karena rasa yang pedas dan aromanya yang tajam. Jumlah kromosom bawang putih lokal ini sebanyak $16=2 \mathrm{n}$. Penelitian ini bertujuan untuk mengetahui pengaruh kolkisin terhadap jumlah kromosom bawang putih (Allium sativum) pada konsentrasi dan lama waktu perendaman yang berbeda. Metode yang digunakan dalam penelitian ini adalah metode eksperimen dengan menggunakan metode squash. Rancangan percobaan yang digunakan adalah percobaan faktorial dengan dua faktor perlakuan. Faktor pertama adalah dosis pemberian larutan konsentrasi kolkisin (D) dengan 3 taraf yaitu : 0,1\% (D1), 0,2\% (D2), dan 0,3\% (D3). Faktor kedua adalah lama waktu perendaman (T) dengan 4 taraf perlakuan yaitu 6 jam (T1), 12 jam (T2), 18 jam (T3), dan 24 jam (T4). Hasil penelitian menunjukkan bahwa kromosom bertambah secara euploid dan aneuploidi yang menyebabkan terbentuknya sel-sel poliploidi. Tipe-tipe poliploidi yang terbentuk yang ditemukan yaitu euploidi yang tetraploid (4n) pada perlakuan D1T2, D2T3 dan D3T4. Kromosom yang bertambah secara aneuploid yaitu $2 n+4$ pada perlakuan D2T2, $2 n+6$ pada perlakuan D1T1; $3 n+6$ pada perlakuan D1T3 dan D1T4; $4 \mathrm{n}+1$ pada perlakuan D2T1 dan T3D3; $4 \mathrm{n}+8$ pada perlakuan D3T2; $5 \mathrm{n}+8$ pada perlakuan D3T1 dan $6 n+4$ pada perlakuan D2T4.
\end{abstract}

Kata kunci: Kolkisin, metode squash, poliploid, aneuploid, euploidi.

\section{EFFECT OF COLCHICINE ON CHROMOSOME NUMBER OF GARLIC (Allium sativum) LOCAL CULTIVARS DOULU}

\section{Tumiur Gultom}

\begin{abstract}
Local garlic cultivars Doulu Doulu from the village of Karo district of North Sumatra. Local garlic Doulu known by the people in North Sumatra because of spicy flavor and aroma sharp. The number of chromosomes local garlic is as much as $16=2 \mathrm{n}$. This study aims to determine the effect of colchicine on the number of chromosomes of garlic (Allium sativum) in the concentration and length of time of immersion is different. The method used in this study is an experimental method using squash. The experimental design used was a factorial trial with two treatment factors. The first factor is the concentration of a solution administered dose colchicine (D) with three levels ie: $0.1 \%$ (D1), $0.2 \%$ (D2), and $0.3 \%$ (D3). The second factor is the length of immersion time (T) with 4 levels are 6-hour treatment (T1), 12 hours (T2), 18 hours (T3), and 24 hours (T4). The results showed that chromosomal aneuploidy increases euploid and that cause cells to polyploidy. Types of polyploidy formed which found that euploidi the tetraploid $(4 \mathrm{n})$ at treatment D1T2, D2T3 and D3T4. Increases aneuploid chromosome is $2 n+4$ on treatment D2T2, $2 n+6$ on treatment D1T1; $3 n+6$ on the treatment D1T3 and D1T4; $4 n+1$ on the treatment D2T1and T3D3; $4 n+8$ on treatment D3T2; $5 n+8$ in treatment D3T1 and $6 n+4$ on D2T4 treatment.
\end{abstract}

Keywords: Colchicine, squash methods, polyploid, aneuploid, euploidi

\section{Pendahuluan}

Penduduk Indonesia yang terus meningkat menyebabkan peningkatan kebutuhan akan makanan dan minuman. Indonesia sebagai salah satu negara yang memiliki jumlah penduduk yang banyak, menjadi tujuan perdagangan terutama 
untuk produk pertanian. Perkembangan impor produk pertanian termasuk produk hortikultura ke Indonesia terus meningkat. Bawang putih salah satu yang mempunyai kecenderungan peningkatan volume impor yang semakin meningkat dan merupakan komoditas yang mempunyai permintaan impor yang paling tinggi dibandingkan dengan produk pertanian lainnya. Bawang putih merupakan tanaman rempah yang bayak digunakan oleh masyarakat Indonesia secara missal. Peningkatan permintaan bawang putih impor dikarenakan meningkatnya konsumsi akan bawang putih (Jumini, 2008).

$$
\text { Dalam rangka }
$$

pengembangan

produktivitas bawang putih lokal maka diperlukan beberapa usaha perbaikan terhadap karakter bawang putih terutama karakter yang mendukung produktivitas bawang putih local. Perbaikan karakter bawang putih lokal untuk meningkatkan kualitas diutamakan pada ukuran umbi tanaman (Anonim, 2013).

Peningkatkan produktivitas dapat ditingkatkan dengan mutasi. Mutasi dapat dibedakan atas mutasi sitologis yakni perubahan bentuk, ukuran, ataupun jumlah kromosom, serta mutasi gen yang secara sitologis tidak tampak namun memengaruhi penampakan fenotif (Crowder, 1986). Mutasi buatan (mutasi induksi) terjadi akibat manipulasi manusia dengan bahan kimia, fisika maupun biologi. Mutasi fisika dapat ditingkatkan dengan menggunakan sinar $\mathrm{X}$, mutasi kimia yang bersifat poliploidi dapat dihasilkan dari induksi kolkisin. Kolkisin dapat menghalangi pembentukan gelendong pembelahan sel sehingga pasangan kromatid pada fase metaphase proses pembelahan sel tidak dapat memisahkan diri dan akhirnya dihasilkan poliploidi. Induksi poliploidi mempunyai ciri-ciri berbuah besar, tidak berbiji, dan produktivitas tinggi (Anonim, 2011).

Kolkisin $\left(\mathrm{C}_{22} \mathrm{H}_{25} \mathrm{O}_{6} \mathrm{~N}\right)$ merupakan suatu alkaloid berwarna putih yang diperoleh dari tanaman Cholchichun autumnale L (Famili liliaceae) (Suminah, et al., 2002), sedangkan menurut Haryanti, et al., (2005) Kolkisin $\left(\mathrm{C}_{22} \mathrm{H}_{25} \mathrm{O}_{6} \mathrm{~N}\right)$ merupakan alkaloid yang mempunyai makrotubula, sehingga salah satu efeknya adalah menyebabkan penggandaan jumlah kromosom tanaman (terbentuk tanaman poliploidi).

Penelitian ini dimaksudkan untuk mengembangkan potensi poliploidi bawang putih local (Allium sativum) kultivar Doulu. Pengembangan bawang putih ini untuk meningkatkan jumlah kebutuhan masyarakat terutaman pada petani bawang.

\section{Bahan dan Metode}

Penelitian dilakukan di Laboratorium Biologi Universitas Negeri Medan Jln. Willem Iskandar Psr. V Medan Estate, pada bulan Mei Agustus 2015.

Bahan yang dipakai pada penelitan ini antara lain ujung akar bawang putih (Allium sativum) yang diperoleh dari kawasan Berastagi dan sekitarnya. Bahan lain yang digunakan adalah kolkisin, asam asetat $45 \%$, asam klorida $1 \mathrm{~N}$, asetokarmin $2 \%$, gliserin, akuades, dan minyak immerse. Sementara alat yang digunakan, botol flakton, gelas penutup, kertas aluminium, kertas label, kertas tisu, kapas, pinset, silet / scalpel, kuas, jarum preparat, pipet dan penggaris, mikroskop cahaya, dan kamera.

Menggunakan rancangan acak kelompok dengan dua faktor. Faktor pertama adalah konsentrasi kolkisin (D) dengan 3 taraf perlakuan yaitu $0,1 \%$ (D1), 0,2\% (D2), dan 0,3\% (D3). Faktor yang kedua adalah lama waktu perendaman $(\mathrm{T})$ dengan 4 taraf perlakuan yaitu 6 jam (T1), 12 jam (T3), 18 jam (T3) dan 24 jam (T4). Kombinasi perlakuan yang diperoleh sebanyak 12 kombinasi perlakuan yaitu : D1T1 ， D1T2， D1T3， D1T4; D2T1, D2T2, D2T3, D2T4; D3T1 D3T2, D3T3, D3T4

Pemilihan Bibit

Bibit dipilih dari umbi yang telah tua dan disinari matahari sekitar 4 hari untuk mematahkan dormansi.

\section{Penanaman Sediaan}

Akar Allium sativum diperoleh dengan merendam umbi sedalam kurang lebih seperempat atau meletakkan umbi diatas kapas basah. Air harus diganti setiap hari untuk mencegah tumbuhnya bakteri dan jamur. Akar akan muncul setelah 2-3 hari, tergantung umur lapis (Radford et al., 1974).

Pembuatan Konsentrasi Kolkisin

Adapun cara pembuatan konsentrasi kolkisin $0,1 \%, 0,2 \%$ dan $0,3 \%$ adalah sebagai berikut:

1. Kolkisin 0,1\%. Kolkisin 0,1 gr dilarutkan dengan $5 \mathrm{ml}$ etanol, lalu ditambah $95 \mathrm{ml}$ akuades dan diaduk hingga larut. Disimpan dalam botol tertutup, berwarna gelap, dalam lemari pendingin bersuhu $5^{\circ} \mathrm{C}$.

2. Kokisin $0,2 \%$. Kolkisin 2 gr dilarutkan dengan $5 \mathrm{ml}$ etanol, lalu ditambah $95 \mathrm{ml}$ akuades dan diaduk hingga larut. Disimpan dalam botol tertutup, berwarna gelap, dalam lemari pendingin bersuhu $5^{\circ} \mathrm{C}$. 
3. Kolkisin 0,3\%. Kolkisin 0,3 gr dilarutkan dengan $5 \mathrm{ml}$ etanol, lalu ditambah $95 \mathrm{ml}$ akuades dan diaduk hingga larut. Disimpan dalam botol tertutup, berwarna gelap, dalam lemari pendingin bersuhu $5^{\circ} \mathrm{C}$.

\section{Pembuatan Kemikalia}

Adapun cara pembuatan kemikalia sebagai bahan tambahan dalam melakukan penelitian ini adalah sebagai berikut:

1. Asam asetat glasial $45 \%$. Asam asetat glacial $45 \mathrm{ml}$ dan $55 \mathrm{ml}$ akuades diaduk hingga larut, lalu disimpan dalam botol tertutup pada suhu kamar.

2. $\mathrm{HCl} 1 \mathrm{~N}$. $\mathrm{HCl}$ pekat dalam 1 bagian ditambah 11 bagian akuades, digojok hingga larut dan disimpan dalam botol tertutup pada suhu kamar (Soesanti dan Setyawan, 2000).

3. Asetoorsein $2 \%$. Asam asetat. Sebanyak $45 \mathrm{ml}$ asam asetat glacial dipanaskan perlahan-lahan hingga hamper mendidih $\left(90^{\circ}-100^{\circ} \mathrm{C}\right)$ ditambahkan 5 gr karmil sedikit demi sedikit lalu didihkan selama \pm 10 menit sambil diaduk. Dinginkan pada suhu kamar lalu ditambahkan $55 \mathrm{ml}$ akuades dan dikocok hingga larut. Disaring dan disimpan pada suhu kamar dalam botol berwarna gelap. Setiap 3 hari penyimpanan biasanya terdapat endapan, untuk itu sebelum digunakan sebaiknya dikocok dan disaring lagi (Wheat Genetict Center, 1997).

\section{Pembuatan Preparat}

Preparat akan dibuat dengan metode squash semi permanen ( Darnaedi $d k k$., 1991) sebagai berikut:

1. Pra-perlakuan. Ujung akar dipotong 23 sampai $5 \mathrm{ml}$, dimasukkan ke dalam botol flakon berisi 2-3 mm kolkisin yang berbeda konsentrasi. Lalu dibungkus ketras aluminium foil dan disimpan dalam lemari es selama 2-4 jam.
2. Pencucian. Kolkisin dibuang dan dicuci dengan akuades sebanyak 3 kali.

3. Fiksasi. Akuades dibuang, diganti asam asetat glacial $45 \%$ dan disimpan dalam lemari es bersuhu $5^{\circ} \mathrm{C}$ selama 15 menit.

4. Pencucian. Asam asetat glacial $45 \%$ dibuang dan dicuci akuades sebanyak 3 kali.

5. Hidrolisis. Akuades dibuang, diganti $\mathrm{HCl} 1 \mathrm{~N}$ dan disimpan dalam oven bersuhu $60^{\circ} \mathrm{C}$ selama \pm 2 menit, tergantung besarnya bahan.

6. Pencucian. $\mathrm{HCl} 1 \mathrm{~N}$ dibuang dan dicuci dengan akuades sebanyak 3 kali.

7. Pewarnaan. Akuades dibuang, diganti asetoorsein 2\% selama 1-3 jam, tergantung ukuran badan dan kesegaran pewarna. Dilakukan pada suhu kamar.

8. Squashing. Diambil 1-2 buah ujung akar dengan kuas, diletakkan diatas gelas benda dan dipotong hingga tersisa 1-2 mm dari ujung. Ditetesi gliserin, ditutup gelas penutup dan diketuk-ketuk, hingga hancur merata

9. Penyegelan. Kelebihan gliserin ditepi gelas penutup dibersihkan dengan tisu, disegel dengan cat kuku bening.

10. Pengamatan. Dilakukan dengan mikroskop cahaya untuk memperbaiki daya resolusi mikrofotografi. Hasil pemotretan diperbesar sehingga mudah diamati.

\section{Parameter pengamatan}

Parameter yang diamati adalah jumlah kromosom yang dihitung pada saat pembelahan sel tahap metafase.

\section{Hasil dan Pembahasan}

Pengamatan pada mikroskop dilakukan pada perbesaran 100x, 400x dan 1000x untuk mengamati jumlah kromosom. Perbesaran 1000x ditampilkan pada Gambar 1.

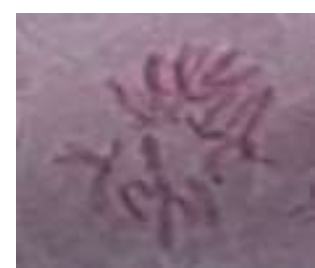

Kontrol

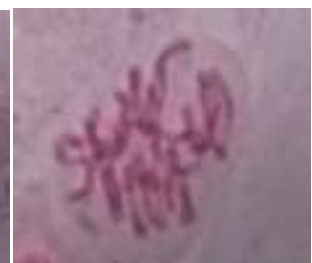

D1T1

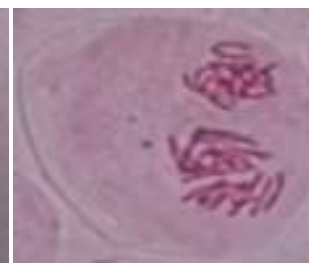

D1T2

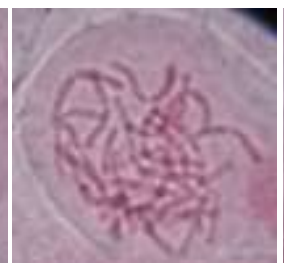

D1T3

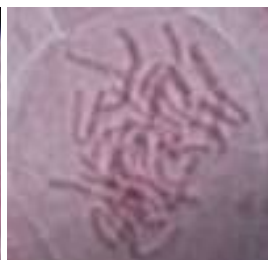

D1T4 


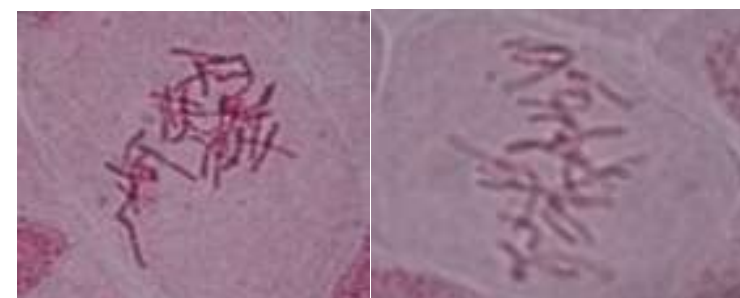

D2T1

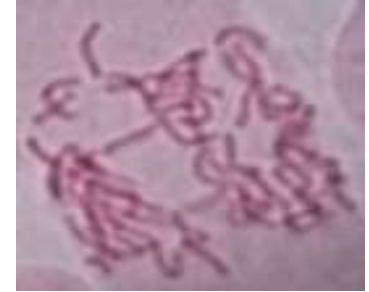

D3T1
D2T2

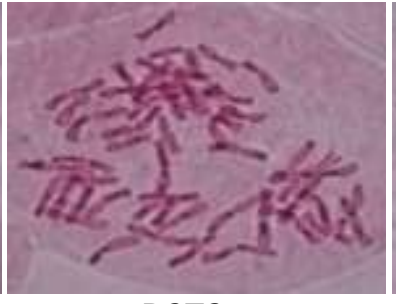

D3T2

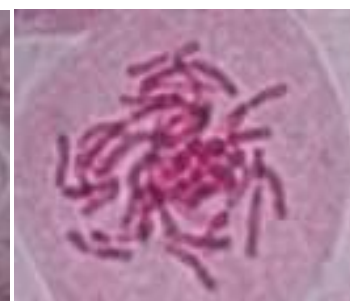

D2T3

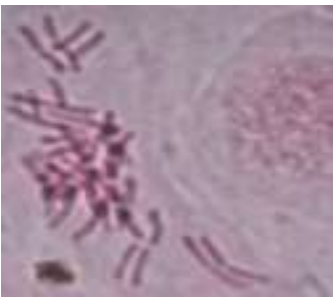

D3T3

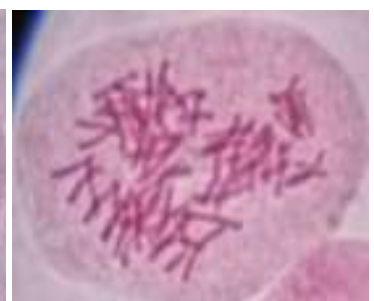

D2T4

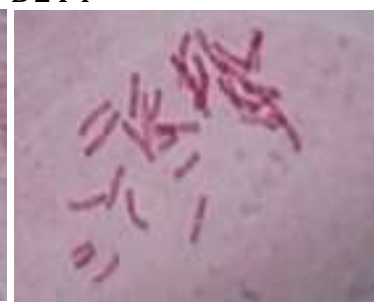

D3T4

Gambar 1. Hasil Pengamatan kromosom bawang putih lokal kultivar Doulu di mikroskop pada perbesaran $1000 \mathrm{x}$

Dari hasil penelitian pengaruh pemberian konsentrasi kolkisin dan lama perendaman terhadap jumlah kromosom bawang putih (Allium sativum) lokal kutivar Doulu yang berbeda memberikan pengaruh yang berbeda dalam pertambahan jumlah kromosom (Tabel 1)

Tabel 1. Jumlah kromosom bawang putih lokal (Allium sativum) kultivar Doulu pada beberapa tingkat konsentrasi kolkisin dengan lama waktu perendaman yang berbeda.

\begin{tabular}{|l|c|c|}
\hline \multicolumn{1}{|c|}{ Kombinasi Perlakuan } & Jumlah kromosom & $\begin{array}{c}\text { Variasi jumlah } \\
\text { Kromosom }\end{array}$ \\
\hline Konsentrasi 0,1\% perendaman 6 jam (D1T1) & 22 & $2 \mathrm{n}+6$ \\
\hline Konsentrasi 0,1\% perendaman 12 jam (D1T2) & 32 & $4 \mathrm{n}$ \\
\hline Konsentrasi 0,1\% perendaman 18 jam (D1T3) & 30 & $3 \mathrm{n}+6$ \\
\hline Konsentrasi 0,1\% perendaman 24 jam (D1T4) & 30 & $3 \mathrm{n}+6$ \\
\hline Konsentrasi 0,2\% perendaman 6 jam (D2T1) & 33 & $4 \mathrm{n}+1$ \\
\hline Konsentrasi 0,2\% perendaman 12 jam (D2T2) & 20 & $2 \mathrm{n}+4$ \\
\hline Konsentrasi 0,2\% perendaman 18 jam (D2T3) & 32 & $4 \mathrm{n}$ \\
\hline Konsentrasi 0,2\% perendaman 24 jam (D2T4) & 54 & $6 \mathrm{n}+4$ \\
\hline Konsentrasi 0,3\% perendaman 6 jam (D3T1) & 48 & $5 \mathrm{n}+8$ \\
\hline Konsentrasi 0,3\% perendaman 12 jam (D3T2) & 40 & $4 \mathrm{n}+8$ \\
\hline Konsentrasi 0,3\% perendaman 18 jam (D3T3) & 33 & $4 \mathrm{n}+1$ \\
\hline Konsentrasi 0,3\% perendaman 24 jam (D3T4) & 32 & $4 \mathrm{n}$ \\
\hline
\end{tabular}

Hasil penelitian menunjukkan bahwa perendaman bawang putih lokal (Allium sativum) dalam kolkisin dengan berbagai konsentrasi memberikan pengaruh yang sangat signifikan terhadap penambahan jumlah kromosom bawang putih. Jumlah kromosom dasar tanaman bawang putih normal adalah $(\mathrm{x}=8)$, sehingga $2 \mathrm{n}=16$. Berdasarkan uji sitologi, induksi kolkisin mengakibatkan penambahan jumlah kromosom normal menjadi tetraploid $(2 \mathrm{n}=4 \mathrm{x}=32)$
Fase pembelahan yang paling bagus untuk mengamati kromosom adalah fase metafase. Hal ini dikarenakan pada tahap metafase kromosom yang menjadi kromatid bergerak menuju bidang equator. Selain itu, kromosom pada tahap ini terlihat sejajar ditengah-tengah equator. Tahap ini dapat dilihat pada Gambar 1.

Penggandaan jumlah kromosom terbanyak terjadi pada pemberian perlakuan kolkisin 0,2 \% pada perendaman 24 jam (D2T4). Hal ini dapat 
diasumsikan bahwa senyawa kolkisin efektif dalam menghambat proses pembelahan sel (antimitosis) sehingga terjadi peningkatan jumlah kromosom (Addink, 2002).

Senyawa kolkisin dapat menghambat terbentuknya benang spindel pada saat mitosis, sehingga kromosom tetap berserakan di dalam sel. Pemberian konsentrasi kolkisin yang tinggi dan perendaman dalam jangka waktu yang lama menyebabkan struktur kromosom dalam sel mengalami penggumpalan dan pengkerutan. Secara umum pemberian senyawa kolkisin lebih efektif dibandingkan mutagen kimia lain seperti ekstrak etanolik daun tapak dara dalam membuat tanaman poliploid. Hal tersebut mungkin disebabkan karena kolkisin murni (pure analytic) yang sudah di purifikasi.

Sedangkan kandungan vinkristin dan vinblastin pada tapak dara masih tercampur dengan senyawa lain dalam ekstrak etanolik tersebut (Indraningsih, 2010). Senyawa kolkisin dapat menginduksi mutasi secara acak, sehingga memberikan efek yang tidak seragam pada masingmasing sel ditiap individu. Pada beberapaa perlakuan kolkisin masih ditemukan individu sel yang tetap diplod (2n). Pada penelitian ini sel-sel yang mengalami penambahan jumlah kromosom atau poliploid hanya ditemukan tipe triploid (3n). Tipe pentaploid (5n), heksaploid (6n) sampai nonaploid (9n) secara hipotesis masih sangat mungkin terbentuk. Dalam penelitian ini kemungkinan juga terjadi peristiwa delesi dan duplikasi pada kromosom. Duplikasi kromosom menyebabkan penambahan materi genetik pada kromosom sedangkan delesi mengakibatkan berkurangnya jumlah kromosom karena hilangnya segmen- segmen kromosom. Adanya delesi dan duplikasi pada kromosom dapat dibuktikan dari beberapa perlakuan kolkisin yang menghasilkan sel dengan jumlah kromosom yang tidak tepat sebagai kelipatan jumlah dasarnya (haploid). Penelitian pada kesuna Bali duplikasi kromosom ditemukan pada perlakuan kolkisin 20\% yang menyebabkan tanaman kesuna bali memiliki jumlah kromosom triploid $(2 n=3 x=24)$ pada penelitian ini ditemukan kromosom tetraploid pada perlakuan $0,2 \%$. Teori ini didukung oleh penelitian Suminah et al. (2002) menyatakan bahwa pemberian kolkisin 1\% mampu memberikan variasi bentuk, ukuran dan jumlah kromosom pada bawang merah (Allium ascalonicum L). Pada level ploidi monoploid (1n) hingga oktaploid (8n), kromosom yang paling sering dijumpai berbentuk metasentris, sedangkan pada individu nonaploid (9n), kromosom yang paling sering dijumpai berbentuk submetasentris.

Induksi kolkisin merupakan mekanisme yang sering digunakan untuk mendorong terjadinya mutasi, sehingga terjadi perubahan bentuk, ukuran dan jumlah kromosom (pengurangan dan penambahan). Dalam penelitian ini, perubahan yang terjadi ditandai secara visual dengan membesarnya ujung akar. Kolkisin dengan kadar 1\% merupakan ambang batas tertinggi yang diperkenankan oleh Eigsti dan Dustin (1957) untuk menginduksi terjadinya mutasi kolkisin dengan konsentrasi yang demikian tinggi ini diberikan dengan harapan daya kerjanya maksimal.

Menurut Eigsti dan Dustin (1957) kolkisin dapat bekerja secara efektif pada konsentrasi $0,001-1 \%$, dengan lama perendaman $6-72$ jam. Namun pada dasarnya setiap tumbuhan mempunyai respon yang berbeda-beda, tergantung jenis dan organ yang diberi perlakuan. Menurut Setyawan (2001) dalam (Jami, 2010) konsentrasi kolkisin $\quad 1 \%$ belum menyebabkan keracunan/kematian akar pada kebanyakan tanaman bawang budidaya (genus alium), dan belum menggumpalkan materi DNA kromosom, sehingga dapat digunakan untuk menelusuri adanya mutasi dengan hasil memuaskan. Berdasarkan jumlah kromosom tanaman bawang putih lokal, senyawa kolkisin menunjukkan perubahan yang bervariasi pada setiap perlakuan. Pada tanaman bawang putih lokal kesuna Bali terjadi perbedaan karakter vegetatif yang diinduksi kolkisin. Bervariasinya karakter vegetatif pada tanaman kesuna Bali disebabkan karena pengaruh mutagen yang bersifat acak (Kahan et al., 2009). Pada penelitian ini tidak sampai mengamati pertumbuhan di lapangan .

Mutagen kolkisin dapat mengakibatkan mutasi sitogenik pada inti sel ditandai dengan perubahan jumlah kromosom ataupun perubahan struktur pada kromosom. Perubahan jumlah kromosom pada tanaman menyebabkan tanaman bersifat poliploid. Tanaman poliploid pada umumnya memiliki sifat dan karakter yang lebih baik dibandingkan tanaman diploidnya (Kristanto dan Kamo, 2001). Konsentrasi kolkisin 0,1\% dengan lama perendaman 12 jam, 0,2\% lama perendaman 18 jam dan $0,3 \quad \%$ kolkisin perendaman 24 jam pada penelitian ini berhasil menghasilkan tanaman bawang putih lokal yang poliploidi yaitu tetraploid $(2 n=4 x=32)$. 


\section{Sifat Morfometri}

Dalam penelitian ini didapatkan ukuran kromosom bawang putih (Allium sativuim) relatif pendek dengan posisi yang tumpang tindih pada kolkisin 0,3 persen sedangkan pada kolkisin $0,1 \%$ dan $0,2 \%$ belum begitu terlihat pendek. Posisi demikian tetap terjadi meskipun pada saat pembelahan mitosis dinding inti hilang dan ruangan sebar kromosom dalam sel meluas. Penumpukan ini mempersulit pengamatan, sehingga bentuk, ukuran dan jumlah kromosom ditentukan secara garis besar, dimana bentuk dan ukuran kromosom hanya dihitung sebagai modus, didasarkan pada kromosom/sel dengan frekuensi tertinggi, sedangkan jumlah kromosom dihitung sebagai pendekatan terhadap jumlah dasarnya (x). Penelitian ini masih merupakan penelitian awal untuk menelaah sifat morfometri dan poliploidi bawang putih lokal Doulu akibat pemberian kolkisin pada konsentrasi $0,1 \%, 0,2 \%$ dan $0,3 \%$.

\section{Tingkat Poliploidi}

Pengaruh kolkisin dalam menginduksi mutasi bersifat acak, sehingga dalam penelitian ini dapat ditemukan individu sel yang tetap bersifat diploid (2n), sebagaimana umumnya sel normal. Serta sel-sel yang mengalami penguranga jumlah kromosom, yakni bersifat monoploid / haploid (1n) dan sel-sel mengalami penambahan jumlah kromosom atau poliploid yang meliputi: tetraploid $(4 n)$, pentaploid $(5 n)$, heksaploid (6n), septaploid (7n), oktaploid (8n) dan nonaploid(9n). Tipe poliploidi yang ditemukan pada penelitian ini adalah tetraploid $(4 n)$

Dalam penelitian ini ditemukan adanya sel-sel normal yang tidak mengalami perubahan jumlah kromosom, bersifat diploid (2n) serta berbagai perubahan jumlah kromosom secara aneuploid yang melahirkan individu poliploid dan perubahan jumlah kromosom secara aneuploid yang menyebabkan jumlah kromosom berkurang atau sedikit berbeda dengan jumlah kelipatan dasarnya. Salah satu bentuk aberasi kromoom yang ditemukan adalah berkurangnya jumlah kromosom karena hilangnya segmen-segmen kromosom (delesi). Hal ini terlihat dengaan adanya kromosom aneuploid (haploid) yang merupakan delesi dari kromosom normal diploid (2n). selain itu ditemukan pula adanya pertambahan materi genetik pada suatu kromosom (duplikasi). Banyaknya sel dengan jumlah kromosom poliploid yang tidak tepat sebagai kelipatan jumlah dasarnya, kemungkinan merupakan akibat delesi dan dupikasi kromosom.
Dalam penelitian ini ditemukan pula penambahan jumlah kromosom secara euploid yang menyebabkan terbentuknya sel-sel poliploid. Berbeda dengan prosedur trangsgenik yang lebih terarah indksi bahan kimia atau radiasi bersifat acak dan tidak teratur, sehingga memberikan efek yang tidak seragam pada masing-masing sel dalam satu individu. Tipe-tipe poliploid yang ditemukan adalah diploid (2n), triploid (3n), tetraploid (4), pentaploid (5n),dan heksaploid (6n). Tipe septaploid (7n), oktaploid (8n) dan nona ploid (9n) tidak ada ditemukan.

Perubahan jumlah kromoom ini disebabkan pemberian kolkisin dengan konsentrasi yang kritis dapat mencegah terbentuknya benang-benag mikrotubul dari gelendong inti (benang-benang spinde) sehingga pemisahan kromosom yang menandai perpindahan dari tahap metafase ke anaphase tidak berlangsung dan menyebabkan penggandaan kromosom tanpa penggandaan dinding sel. Oleh karena tidak terbentuk benang spindel maka kromosom tetap dalam sitoplasma. Namun kromosom tidak memisah dari sentromernya dan dimulai tahap canafase yang dilanjutkan dengan pembentukan dinding inti. Sehingga sel mengandung jumlah kromosom berlipat 2. Apabila konsentrasi kritis dibiarkan terus berlanjut maka pertambahan genom akan mengikuti deret ukur (Suryo, 2008).

Dalam penelitian ini perhitungan jumlah kromosom dilakukan secara pembulatan, mengingat mutasi sering terjadi secara euploid, dimana perubahan jumlah kromosom sering kali merupakan kelipatan jumlah kromosom dasarnya. Apabila jumlah kromosom yang terhitung berada diatas atau bawah kelipatan jumlah kromosom dasar, maka dapat diduga telah terjadi delesi atau duplikasi, namun hal ini juga dapat merupakan akibat kesalahan teknik penghitungan, oleh karena itu dipilih pembulatan. Keanekaragaman genetik yang disebabkan oleh mutasi sumber plasma nutfah untuk program pemuliaan tanaman. Keanekaragaman ini memungkinkan untuk mengetahui bayak karakter gen sehingga dapat dijadikan sebagai salah satu penemuan kultivar unggul (Anggarwulan et al., 1999; Suryo, 2008).

Dalam dunia pertanian peningkatan keanekaragaman genetik akibat mutasi, rekombinasi serta separasi dan segregasi selama meiosi merupakan sumber plasma nutfah untuk pemuliaan tanaman. Keanekaragaman ini dapat terjadi secara spontan dengan laju yang rendah atau dapat diinduksi oleh pengaruh kimia atau fisik dengan mematahkan kromosom atau mengubah 
perilakuannya selama pembelahan meiosis atau mitosis (Crowder, 1986).

Keanekaragaman ini memungkinkan untuk mengetahui banyak karakter gen, sehingga aberasi dan poliploidi mempunyai nilai tinggi dalam penemuan kultivar unggul. Tanaman poliploid biasanya lebih kuat dari pada tanaman diploid, ukuran daun, batang, bunga, buah, dan inti sel lebih besar, kandungan vitamin dan protein bertambah, tekanan osmotic berkurang, serta pembelahan sel melambat, sehingga umur vegetatip lebih, (Suryo, 2008).

\section{Kesimpulan}

Perbandingan konsentrasi dan lama perendaman yang berbeda memberikan ploidi yang berbeda dalam pertambahan jumlah kromosom bawang putih (Allium sativum) secara euploid dan uneuploidi. Ploidi yang euploidi menghasilkan $2 \mathrm{n}=4 \mathrm{x}=32$ adalah pada konsentrasi $0,1 \%$ lama perendaman 12 jam (D1T2), konsentrasi $0,2 \%$ lama perendaman 18 jam dan konsentrasi $0,3 \%$ lama perendaman 24 jam (D3T4).

\section{Ucapan Terima Kasih}

Terima kasih kepada Mika Anita $\mathrm{Br}$ Perangin-angin yang telah membantu pelaksanaan penelitian di Laboratorium.

\section{Daftar Pustaka}

Addink, W., (2002). Colchicine: use in plant breeding work to induce mutation (polyploidy). from: Opened at: 18.09.2014.08.45.

Aggarwulan, E., N. Etikawati, dan A.D. Setyawan., (1999). Karyotipe Kromosom pada Tanaman Bawang Budidaya (Genus Allium; Familia: Amaryllidaceae). BioSMART 1 (2): 13-19.

Anonim,

http:www.anneahira.com/bawangputih.html (diakses februari 2015).

Anonim, (2013), http://obat-tradisionalmengobati/2013/03/klasifikasitumbuhan-bawng-putih.html (diakses Februari 2015)

Cahyono,B., (1996). Budidaya bawang putih dataran rendah (usaha mengembangkan, memasarkan dan analisis produksi). Cv Aneka, Solo.

Crowder, L, V., (1986). Genetika Tumbuhan. Gadjah Mada University Press, Yogyakarta.
Eigsti dan Dustin, (1957). Colchicine in Agriculture, Medicine, Biology and Chemistry. AmesLowa: The Lowa State College Press.

Haryanti, Rini Budi Hastuti, Nintya Setiari, Dan Agung Banowo., (2005). Pengaruh Kolkisin Terhadap Pertumbuhan, ukuran Sel Metafase Dan Kandungan Protein Biji Tanaman Kacang Hijau ( Vigna radiate L Wilczek). Jurnal Penelitian Sains Dan Teknologi, Vol 10, No 2, 2009: 112-120

Indraningsih, E., (2008). Induksi Poliploidisasi Bawang Merah (Allium cepa L.) dengan Ekstrak Etanolik Daun Tapak Dara (Catharanthus roseus [L] G. Don.). Seminar. Fakultas Biologi Universitas Gadjah Mada: Yogyakarta.

Kimball, J.W., (1983). Biology $3^{\text {rd }}$ ed. John Willey and Sons, Inc., New York.

Jumini, (2008). Analisis Faktor-faktor yang mempengaruhi permintaan bawang putih di Indonesia. IPB Press. Bogor.

Kristianto, B.A ., B. Sukamto dan Karno, (2001). Poliploidasi rumput makanan ternak dalam rangka mendapatkan rumput unggul. Jurnal pengembangan peternakan tropis (Edisi Spesial): 172-180

Lamina, (1989). Petunjuk teknik budidaya bawang putih. CV. Simplex, Jakarta.

Okada, H. (1981), Report on trainings and investigations in LBN-LIPI, Osaka: Departemen of Biology Osaka University.

Radfort, A, E., Et All. (1974). Vascular plant Sistematics, New York: Harper and Row Publishers.

Rismunandar, (1989). Membudidayakan lima jenis bawang. Sinar Baru, Bandung.

Sastrosumarjo, (2006). Sitogenetika Tanaman. IPB Press Bogor.

Stack. S, M. (1979). The Cromosome and DNA of Allium cepa. CROMOSOME. 70:161-181

Suminah, Sutarno, dan Setyawan A.D. (2002). Induksi poliploidi bawang merah (Allium ascalonicum L.) dengan pemberian kolkisin. BIODIVERSITAS. 3(1): 174-180

Suprihati, D., Elimasni, E. Sabri, (2007). Identifikasi kariotipe Terong belanda (Solanum betaceum cav.). Kultivar Berastagi Sumatera Utara. Jurnal Biologi Sumatera Utara, 2(1): 7-11

Suryatinah. S., (1998). Pengaruh pemberian kolkisin terhadap jumlah kromosom, distribusi serta usuran stomata dan kadar minyak atsiri pada bawang ptih (Allium sativum). Skripsi 
Fakultas Pertanian Universitas Gadjah Mada, Yogyakarta.

Suryo, (2008). Sitogenetika. Gadjah Mada University Press, Yogyakarta.
Wibowo, Singgih, (1989). Budidaya bawng (Bawang putih, bawang merah, bawang Bombay). Swadaya, Jakarta. 